\title{
Waterpipe tobacco smoking (WTS) control policies: global analysis of available legislation and equity considerations
}

\author{
Hala Alaouie (1) , ${ }^{1}$ Sumithra Krishnamurthy Reddiar, ${ }^{2}$ Malak Tleis, ${ }^{3}$ Lama El Kadi, ${ }^{3}$ \\ Rima A Afifi (1) , ${ }^{4}$ Rima Nakkash (1) 3,5
}

\begin{abstract}
- Additional supplemental material is published online only. To view, please visit the journal online (http://dx.doi. org/10.1136/tobaccocontrol2021-056550).
\end{abstract}

'Department of Social and Policy Sciences, University of Bath, Bath, UK

${ }^{2}$ Independent Researcher, Texcoco, Mexico

${ }^{3}$ Health Promotion and Community Health Department, American University of Beirut, Beirut, Lebanon

${ }^{4}$ College of Public Health, University of lowa, lowa City, Iowa, USA

${ }^{5}$ Global and Community Health Department, College of Health and Human Services, George Mason University, Fairfax, Virginia, USA

\section{Correspondence to} Dr Rima Nakkash, Health Promotion and Community Health, American University of Beirut, Beirut, Lebanon; rn06@aub.edu.lb

HA and SKR are joint first authors.

Received 8 July 2021 Accepted 6 January 2022

\section{Check for updates}

(C) Author(s) (or their employer(s)) 2022. No commercial re-use. See rights and permissions. Published by BMJ.

\section{To cite: Alaouie $\mathrm{H}_{\text {, }}$} Krishnamurthy Reddiar S, Tleis M, et al. Tob Control 2022:31:187-197.

\begin{abstract}
Introduction The Framework Convention on Tobacco Control (FCTC) offers guidance on evidence-based policies to reduce tobacco consumption and its burden of disease. Recently, it has provided guidance for alternative tobacco products, such as the waterpipe. Waterpipe tobacco smoking (WTS) is prevalent worldwide and policies to address it need to take into consideration its specificities as a mode of smoking. In parallel, a growing body of literature points to the potential of evidencebased tobacco control policies to increase health inequities. This paper updates a previous global review of waterpipe tobacco policies and adds an equity lens to assess their impact on health inequities.

Methods We reviewed policies that address WTS in 90 countries, including 10 with state-owned tobacco companies; 47 were included in our final analysis. We relied primarily on the Tobacco-Free Kids organisation's Tobacco Control Laws website, providing access to tobacco control laws globally. We categorised country tobacco policies by the clarity with which they defined and addressed waterpipe tobacco in relation to nine FCTC articles. We used the PROGRESS (Place of residence, Race/ethnicity/culture/language, Occupation, Gender/sex, Religion, Education, Socioeconomic status and Social capital) framework for the equity analysis, by reviewing equity considerations referenced in the policies of each country and including prevalence data disaggregated by equity axis and country where available.
\end{abstract}

Results Our results revealed very limited attention to waterpipe policies overall, and to equity in such policies, and highlight the complexity of regulating WTS. We recommend that WTS policies and surveillance centre equity as a goal.

Conclusions Our recommendations can inform global policies to reduce WTS and its health consequences equitably across population groups.

\section{INTRODUCTION}

Waterpipe tobacco smoking (WTS) prevalence has been increasing over the past two decades-mostly driven by youth use-in many countries around the world, mainly located in the Eastern Mediterranean and European regions. ${ }^{1}$ The health-related harms caused by WTS are well documented and mirror those caused by cigarettes. ${ }^{2-5}$ In addition, the sharing of waterpipes between users carries risk of spread of infectious diseases. ${ }^{67}$

The rapid global spread of WTS has been linked to a variety of factors, including a lack of waterpipe-specific regulations. ${ }^{5} 8$ The unique features of WTS in comparison with cigarettes, such as the tobacco itself (flavouring and packaging), waterpipe components (hose, mouthpiece, liquid, base), toxicant exposure and physiological effects, WTS use patterns (in homes and restaurants or cafes), positive social norms associated with it, and the lax policy environment, require specific attention in policy regulation, and adaptation of the guidance usually focused solely on cigarettes. ${ }^{910}$ The guiding document for global tobacco control regulation is the Framework Convention on Tobacco Control (FCTC), the world's first global health treaty, which includes evidence-based policy recommendations translated through required 'articles'. Research evidence and reports from the Conference of the Parties (COP) to the FCTC on global regulatory practices have documented potentially effective regulatory practices for WTS, ${ }^{11-14}$ such as using waterpipe-specific health warning labels. As a result, global health guidance is emerging on WTSspecific policies. ${ }^{15-18}$

Even beyond these policy recommendations, tobacco control advocates have begun to discuss the tobacco 'endgame' - a vision of less than 5\% population prevalence of tobacco smoking. Achieving the endgame will require fundamental shifts in the 'structural, political and social dynamics that sustain the (tobacco) epidemic'. ${ }^{19}$ Several strategies for reaching this target have been suggested, ${ }^{20}$ including a focus on supply-oriented endgame models, such as state-owned tobacco companies (SOTC). ${ }^{21} 22$ Analysis of the scope of conflicts of interest related to SOTC and robust tobacco control policies suggests potential for a partial alignment of interests, based on WHO's guidance on implementation of Article 5.3 of the FCTC, which includes the suggestion 'to impose a requirement (on SOTC) to consider social and environmental consequences and to take certain steps to address those consequences'. ${ }^{21}$ Given the increasing rhetoric in the scientific and advocacy community around the endgame strategy and the importance of regulation of alternative tobacco products such as WTS to achieving the endgame, ${ }^{23}$ beginning to explore the scope of WTS policies and the extent to which social and environmental consequences are considered in countries with SOTC is critical.

In principle, policy development and enforcement covers the whole population and therefore is assumed to be equitable. Yet a growing body of literature points to the potential for tobacco control 
policies to increase inequities. ${ }^{19-22} 2425$ Applying an equity lens to policies goes beyond disaggregating data by sociodemographics to considering 'social, behavioral, economic and environmental determinants, and (working) collaboratively with community stakeholders'. ${ }^{26}$ Systematic reviews of population-level general tobacco control interventions and policies for youth and adults found a majority to have negative, mixed or unclear impacts on inequities. ${ }^{27-29}$ This has led to calls to adopt an equity perspective to tobacco control policymaking ${ }^{30}$ and use theory as a guide. ${ }^{28}$ Several frameworks/theories generally, ${ }^{31-34}$ and specific to tobacco control, ${ }^{35} 36$ allow careful analysis of policies in relation to health equity outcomes. Many highlight the critical need for attention to the political, economic and structural determinants of health-and for the importance of shifting power dynamicsfor significant decreases in inequities to occur. WTS has rarely been a specific focus of studies on equity outcomes of policies. Comparisons of WTS prevalence by sociodemographic characteristics are common, but not analysed from a broader equity lens (eg, refs 8253132 37).

The aim of this paper is to assess the current status of specific waterpipe tobacco (WT) policies globally using nine FCTC articles as a reference. In this process, we provide an update to the Jawad $e t a l^{38}$ policy review. We also specifically include countries with SOTC to explore their potential to advance the endgame strategy. Further, this paper will use the PROGRESS framework to apply an equity lens to the policies and analyse prevalence data to highlight differences in WTS. The PROGRESS framework recommends stratification of data by Place of residence, Race/ethnicity/culture/language, Occupation, Gender/sex, Religion, Education, Socioeconomic status and Social capital. ${ }^{33}$ The framework 'highlight[s] the multidimensionality of the distribution of health among population subgroups' and is helpful in understanding the impact of policies on equity. ${ }^{34}$

\section{METHODS}

We used publicly available data sources to abstract information to (1) identify countries with legislation that addresses WTS and (2) identify WTS prevalence data for these corresponding countries. For the equity analyses, given the dearth of attention to inequities in relation to WTS, we chose to apply a relatively straightforward framework: PROGRESS. ${ }^{34} 35$

In the following sections, we describe the data sources, eligibility criteria, search strategy and data abstraction processes.

\section{WTS legislation}

Our main source of data on WTS policy-relevant legislation was the 'Tobacco Control Laws' (TCL) website, ${ }^{36}$ a project of the International Legal Consortium of the Campaign for TobaccoFree Kids. This website provides a one-stop-shop to analyse country-related policies organised along themes consistent with FCTC articles. Jawad $e t a l^{38}$ also relied on this site, so screening of countries began with the list of countries included in that paper $(n=62)$. We then updated that list with countries included in a more recent WHO FCTC COP report on regulatory practices related to waterpipe use $(\mathrm{n}=19) .{ }^{18}$ Finally, we supplemented this list by including countries with SOTC found in Hogg et $a l^{21}$ that were not included in either of the other lists $(n=9)$. Thus, a total of 90 countries were screened within the TCL website for policies related to WTS (see online supplemental appendix 1).

Some countries had one tobacco control policy, while others had several policies related to tobacco control. We extended our search beyond the TCL website for four countries. These included Jordan, whose law on the TCL website was only in

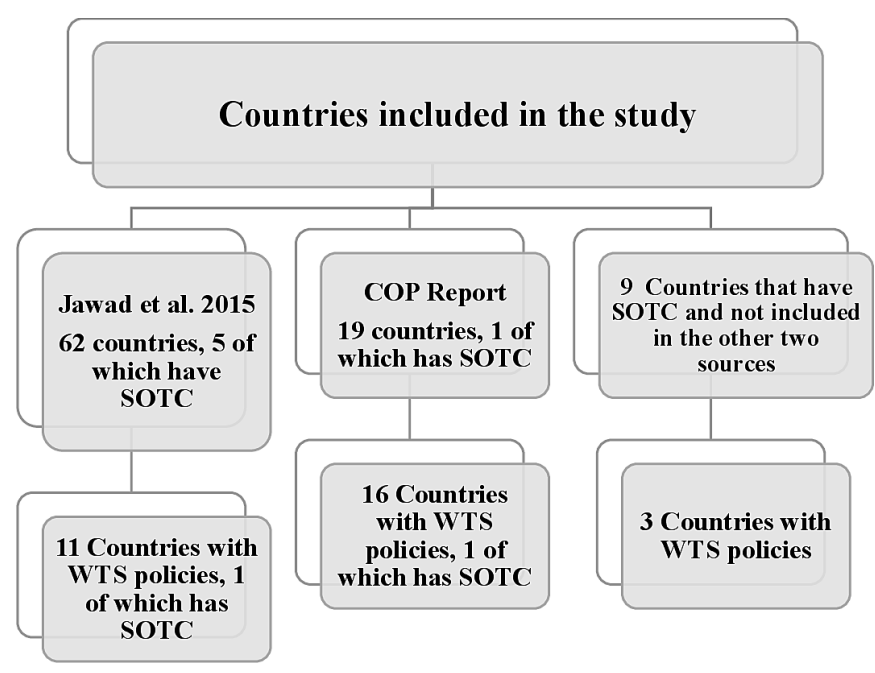

Figure 1 Flow chart of screening and selection. COP, Conference of the Parties; SOTC, state-owned tobacco companies; WTS, waterpipe tobacco smoking.

draft form; Egypt, which the authors knew had a WTS-specific health warning law that was not on the TCL website; the Netherlands, whose law on the TCL website was in Dutch; and the UK, given potential changes to regulations resulting from Brexit which led to finding an additional policy document for Wales. We found relevant documents in all these cases except for the Netherlands (no translation was found) and Jordan.

\section{Eligibility criteria}

For the country tobacco control policies to be included in our review, the word waterpipe or related words (water pipe, shisha, chicha, hookah, hukkah, nargileh, argileh, arghileh, narghileh, hubble bubble, hobble bobble) had to be mentioned at least once in any of the country's policy document. ${ }^{38} 39$ Contrary to Jawad et al, ${ }^{38}$ we did not include countries that only referenced FCTC Article 1(f), which defines tobacco products as 'products entirely or partly made of the leaf tobacco as raw material which are manufactured to be used for smoking, sucking, chewing or snuffing'. Generic definitions of tobacco products that do not specifically include waterpipe (or its related words) are open to interpretation and lead to wide variation in implementation. This was the only difference in the categorisation of country WTS policies as compared with Jawad et al. ${ }^{38}$

The initial screening led to identifying 53 countries that met the above eligibility criteria. Six countries (Argentina, Canada, Jordan, Laos, Namibia, South Africa) were excluded from further analysis as they only referred to waterpipe as an accessory/device and did not link it to any FCTC article. Regulating only accessories is not sufficient and is potentially an attempt to circumvent actual effective legislation. For the other 47 countries, we reviewed the entire content of the policy and abstracted any text that mentioned waterpipe. Figure 1 is a flow chart of the screening and selection process.

\section{Document analysis search strategy}

Two reviewers independently reviewed each country's legislation and abstracted any portion of the document that included the word waterpipe (or related search terms), its definition and specifically any regulation associated with the following nine articles of the FCTC: 6, 8-16. These articles suggest evidencebased regulation in the following areas: 
- Article 6: price and tax measured to reduce demand for tobacco.

- Article 8: protection from exposure to tobacco smoke.

- Article 9: regulation of the contents of tobacco products.

- Article 10: regulation of tobacco product disclosure.

- Article 11: packaging and labelling of tobacco products.

- Article 12: education, communication, training and public awareness.

- Article 13: tobacco advertising, promotion and sponsorship.

- Article 14: demand reduction measures concerning tobacco dependence and cessation (we combined Articles 12 and 14 in our analysis).

- Article 15: illicit trade in tobacco products.

- Article 16: sales to and by minors.

Subsequently, reviewers assessed any association of the word waterpipe with PROGRESS equity-related axes.

\section{Data abstraction}

The research team developed a spreadsheet which was used by the two reviewers to independently abstract data. In case of disagreements, a third or/and fourth reviewer (authors on this paper) were consulted.

\section{Data analysis}

We used document analysis as our analytical tool, specifically considering 'documents as sources'. ${ }^{40}$ In this method of document analysis, 'the researcher is interested in what documents reveal about the real (material) world, how they reflect the actions or interests of political actors or how they describe the contents of a given law' (185). ${ }^{40}$ This allowed the analysis of WTS country tobacco policies and resulted in the categorisation of five types of policy (table 1).

\section{Category 1}

The definition of a 'tobacco product' includes WT. WT is not mentioned specifically in any of the remaining policy clauses. The assumption is that it is regulated throughout the policy wherever the term 'tobacco product' is used.

\section{Category 2}

The tobacco product definition includes WT, and the policy specifically addresses WT in at least some articles.

\section{Category 3}

The tobacco product definition includes WT. However, they specifically exclude WT in some articles where other tobacco products are addressed.

\section{Category 4}

The tobacco product definition is generic and does not refer to any specific product including WT. However, specific policy documents or clauses address WT. We subcategorised this category into subcategory A: the country has a specific decree or legal notice related to waterpipe; and subcategory B: WT is mentioned in one article of the law.

The document analysis also allowed the identification and description of any equity-related content in the policy, along the PROGRESS axes.

\section{Prevalence data}

We searched for data on WTS prevalence in the 47 countries whose policies included content related to WTS. We originally explored many commonly used global-level health databases (online supplemental table 2). However, we found only a few that reported WTS prevalence data.

\section{Eligibility criteria}

We used only publicly available data, documenting prevalence from 2015 to March 2020. We only included national-level WTS prevalence data and only when it was disaggregated from other tobacco or non-cigarette products.

\section{Search strategy}

From the databases, we included any indicators that measured waterpipe or any variation, such as 'water pipe', 'narguileh', 'hookah', 'hukkah', 'shisha', 'waterpipe with tobacco' and 'calean with tobacco', among 'current smokers' (defined varyingly across different data sources). These terms differ slightly from the policy search terms as we relied on terms used in the reports.

\section{Data abstraction}

Two reviewers independently extracted the data into a spreadsheet by capturing information from all sources as reported. This spreadsheet was then used for manipulation as presented in the results section.

\section{Data analysis}

We extracted the data pertaining to WTS prevalence as reported in the surveys and found that, of the 47 countries included in the policy analysis, 25 reported at least one measure of WTS prevalence. We found seven countries that reported WTS prevalence across two data sets. For the extraction to include an equity lens, we considered the PROGRESS framework. For countries where

\begin{tabular}{|c|c|c|}
\hline $\begin{array}{l}\text { Category of WT } \\
\text { policy* }\end{array}$ & Description & Included countries* \\
\hline 1 & The tobacco product definition includes WTS. & $\begin{array}{l}\text { Azerbaijan, Chad, Costa Rica, Ecuador, France, India, Iraq, Kingdom of Saudi Arabia, } \\
\text { Moldova, Pakistan, Panama, Philippines, Serbia, Vietnam, Yemen. }\end{array}$ \\
\hline 2 & $\begin{array}{l}\text { The tobacco product definition includes WTS and they specifically address WTS in } \\
\text { all or some articles. }\end{array}$ & Afghanistan, Bahrain, Russia, Singapore, Turkey, United Arab Emirates. \\
\hline 3 & $\begin{array}{l}\text { The tobacco product definition includes WTS. However, they specifically focus on } \\
\text { other tobacco products in some articles, which intentionally exclude WTS. }\end{array}$ & $\begin{array}{l}\text { Bulgaria, Czech Republic, England, Northern Ireland, Poland, Portugal, Scotland, } \\
\text { Slovakia, Slovenia, Sweden, Wales. }\end{array}$ \\
\hline $4 B$ & $\begin{array}{l}\text { The policy has a generic definition of tobacco products that does not specifically } \\
\text { include WT but specific clauses within the policy address WT. }\end{array}$ & Estonia, Egypt, Ireland, Nigeria, Norway, Uganda, Ukraine. \\
\hline
\end{tabular}


Table 2 WTS definitions in the tobacco policies by country

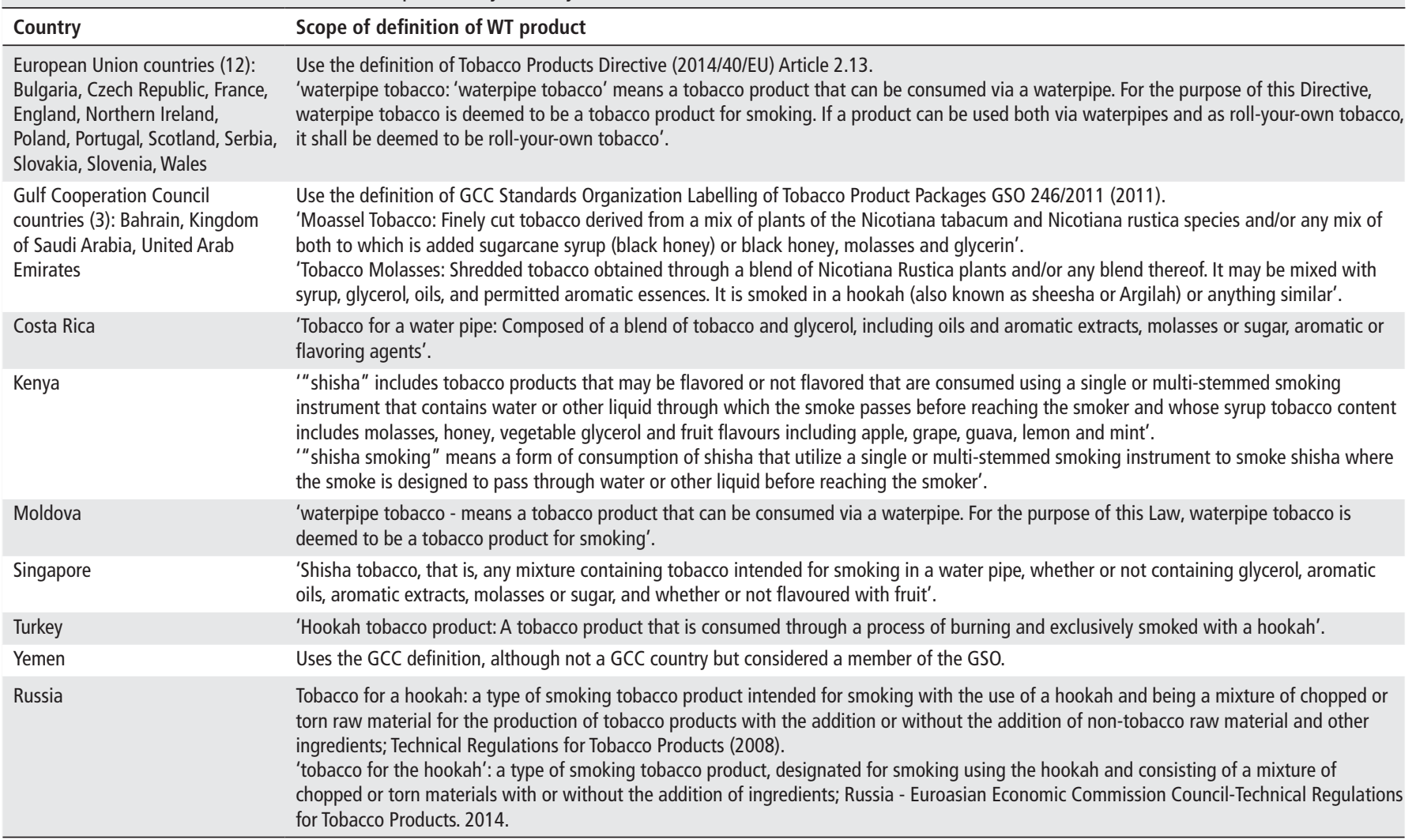

GCC, Gulf Cooperation Council; GSO, GCC Standardization Organization; WT, waterpipe tobacco; WTS, waterpipe tobacco smoking.

WTS was reported over two or more data sets, we used the most recent report. We report bivariate results by the PROGRESS equity axes as reported in the data sources.

\section{RESULTS}

\section{Policy analysis}

Within the 47 country policies, 22 provided a definition of what they considered to be a WT product (table 2). Additionally, within the policies, irrespective of definition, waterpipe was referred to as a smoking device by 2 countries (Lebanon, Mauritius), as a smoking device and a tobacco product by 8 countries (Azerbaijan, Costa Rica, Estonia, Iraq, Thailand, United Arab Emirates, Uganda, Russia), or only as a tobacco product by the remaining 37 countries.

Out of the 47 countries, $21.3 \%$ are in the East Mediterranean Region (EMR), 6.4\% are in Western Pacific Region (WPR), $44.7 \%$ are in the European Region (EUR), $10.6 \%$ are in the South-East Asia Region (SEAR), $8.5 \%$ are in the Region of the Americas (AMR) and $8.5 \%$ are in the African Region (AFR). Out of the 44 countries categorised by the World Bank (excluding Wales, Scotland and Northern Island, which were not categorised by the World Bank), 18.2\% were low-income economy (LIE), 34.1\% were high-income economy (HIE), 29.5\% were upper middle-income economy (UMIE) and 18.2\% were low middle-income economy (LMIE).

Within category $1,8.5 \%$ of the countries are in the EUR, $2.1 \%$ in the AFR, $6.4 \%$ in the AMR, $8.5 \%$ in the EMR and $4.3 \%$ in the WPR. These countries were distributed as follows: 9.1\% belonged to LMIE, $4.5 \%$ belonged to HIE, 6.8\% belonged to LIE and $13.6 \%$ belonged to UMIE. Within category $2,8.5 \%$ of the countries are in the EUR, 6.4\% in the EMR and 2.1\% in the WPR. These countries were distributed as follows: $6.8 \%$ belonged to HIE, 2.3\% belonged to LIE and $4.5 \%$ belonged to UMIE. Within category 3, 23.4\% are in the EUR, out of which 15.9\% were HIE and 2.3\% UMIE. Within category 4A, 2.1\% are in the AMR, 2.1\% in the EMR, 2.1\% in the SEAR and 6.4\% in the AFR. These countries were distributed as follows: $2.3 \%$ were LMIE, 6.8\% were LIE and 4.5\% were UMIE. Within category $4 \mathrm{~B}, 8.5 \%$ are in the EUR, $2.1 \%$ in the EMR and $4.3 \%$ in the SEAR. These countries were distributed as follows: $6.8 \%$ were HIE, 2.3\% were LIE and 6.8\% were LMIE.

\section{Categorisation of policies in relation to WT}

Overall, 32\% of countries with WTS policies were classified as category $1,13 \%$ as category $2,23 \%$ as category $3,13 \%$ as category $4 \mathrm{~A}$ and $15 \%$ as category $4 \mathrm{~B}$ (table 1 ). Due to word limitations, we include exemplar content from only one relevant country policy document for each category described in the Methods section.

\section{Category 1}

Fifteen countries had WTS policies that fell into category 1. Vietnam defines a tobacco product as the following: 'Tobacco means a product made from the whole or part of the tobacco material processed in the form of cigarette, cigar, loose tobacco fiber, water pipe tobacco and other types' (Vietnam - 2012 Tobacco Control Law).

\section{Category 2}

Six countries had WTS policies that fell into category 2. In Russia, an amendment was introduced in 2020 to several federal laws that entailed the addition of the word hookah to the articles in text. As one example, in the Code of the Russian Federation 
on administrative violations, it was recommended to 'supplement the title after the word "tobacco" with the words "the use of nicotine-containing products or the use of hookahs".

\section{Category 3}

Eleven countries had WTS policies that fell into category 3. In the Czech Republic (Act No. 100/1997, amended 2016), they prohibit marketing of certain cigarettes, but not waterpipe: 'The placing on the market of cigarettes with a characterising flavour and roll-your-own tobacco with a distinctive flavour is prohibited'.

\section{Category 4}

Subcategory A

Six countries had WTS policies that fell into category 4A. In Syria, WT is mentioned in one of the articles related to the textual requirement for no smoking signs: 'A symbol and a phrase denoting prohibition of smoking tobacco products, that is, cigarettes, water-pipes, cigars or tobacco-pipes, etc'.

\section{Subcategory B}

Seven countries had WTS policies that fell into category 4B. In Kenya, in the legislative supplement (No. 56) of 2007, a picture of a waterpipe appears randomly without any link to the policy and describes it as a smokeless tobacco product (figure 1).

\section{WT policy regulations in relation to specific FCTC articles}

We analysed the inclusion of WTS regulation related to nine specific FCTC articles $(6,8-11,12 / 14,15-16)$. Four countries (8\%) included seven of the FCTC articles in their WTS policy. More specifically, over half of the countries included in our analysis regulated WT in relation to FCTC Articles $11(\mathrm{n}=26), 16$ $(n=25), 13(n=23)$ and $8(n=22)$. Less than $20 \%$ of the countries included in our analysis regulated WT in relation to Articles $6,9,10(\mathrm{n}=8)$ and $15(\mathrm{n}=2)$.

Table 3 lists the countries by FCTC article that it includes in its regulation related to WT.

Table 3 Country categorisation by reference to FCTC articles specifically in relation to WT in their policies

\begin{tabular}{|c|c|c|c|c|c|}
\hline $\begin{array}{l}\text { Country (WHO region, WB } \\
\text { categorisation) }\end{array}$ & $\begin{array}{l}\text { FCTC articles addressed in relation } \\
\text { to WT }\end{array}$ & $\begin{array}{l}\text { Total number of } \\
\text { articles addressed }\end{array}$ & $\begin{array}{l}\text { Country (WHO region, WB } \\
\text { categorisation) }\end{array}$ & $\begin{array}{l}\text { FCTC articles that specifically } \\
\text { address WT }\end{array}$ & $\begin{array}{l}\text { Total number } \\
\text { of articles } \\
\text { addressed }\end{array}$ \\
\hline Category 1 & & & Category 3 & & \\
\hline Azerbaijan (EUR, LIE) & $8,12 / 14,13,16$ & 4 & Bulgaria (EUR, UMIE)* & 11 & 1 \\
\hline Chad (AFR, LIE) & 11 & 1 & Czech Republic (EUR, HIE) & $10,11,12 / 14,15$ & 4 \\
\hline Costa Rica (AMR, UMIE) & $8,9,10,12 / 14,16$ & 5 & England (EUR, HIE) & $10,11,13,15$ & 4 \\
\hline Ecuador (AMR, UMIE) & $8,9,10,11,13$ & 5 & Northern Ireland (EUR) & $10,11,13$ & 3 \\
\hline France (EUR, HIE) & $10,11,13,16$ & 4 & Poland (EUR, HIE) & 11 & 1 \\
\hline India (SEAR, LMIE) & 13 & 1 & Portugal (EUR, HIE) & $8,9,11,12 / 14,13,16$ & 6 \\
\hline Iraq (EMR, UMIE)* & $8,9,11,13,16$ & 5 & Scotland (EUR) & $10,11,13$ & 3 \\
\hline $\begin{array}{l}\text { KSA (Kingdom of Saudi Arabia) } \\
\text { (EMR, HIE) }\end{array}$ & $8,10,11,12 / 14,13,16$ & 6 & Slovakia (EUR, HIE) & 10,11 & 2 \\
\hline Moldova (EUR, UMIE)* & $8,9,10,11,12 / 14,13,16$ & 7 & Slovenia (EUR, HIE) & $8,10,11,12 / 14,13,16$ & 6 \\
\hline Pakistan (EMR, LMIE) & 6,16 & 2 & Sweden (EUR, HIE) & 11 & 1 \\
\hline Panama (AMR, UMIE) & $8,10,11,12,13$ & 5 & Wales (EUR) & $10,11,13$ & 3 \\
\hline Philippines (WPR, LMIE) & $8,11,12 / 14,13,16$ & 5 & Category $4 \mathrm{~A}$ & & \\
\hline Serbia (EUR, UMIE) & $8,12 / 14$ & 2 & Brazil (AMR, UMIE) & $8,11,13$ & 3 \\
\hline Vietnam (WPR, LMIE)* & $6,8,9,11,12 / 14,13,16$ & 7 & Kenya (AFR, LMIE) & 13,16 & 2 \\
\hline Yemen (EMR, LIE) $)^{*}$ & $6,8,9,11,12 / 14,13,16$ & 7 & Niger (AFR, LIE) & 16 & 1 \\
\hline Category 2 & & & Rwanda (AFR, LIE) & $8,13,16$ & 3 \\
\hline Afghanistan (EMR, LIE) & $6,8,11,12 / 14,13,15,16$ & 7 & Syria (EMR, LIE)* & $8,11,12 / 14,13,16$ & 5 \\
\hline Bahrain (EMR, HIE) & 11 & 1 & Thailand (SEAR, UMIE)* & 16 & 1 \\
\hline Russia (EUR, UMIE) & $6,8,10,11,13,16$ & 6 & Category 4B & & \\
\hline Singapore (WPR, HIE) & 13,16 & 2 & Estonia (EUR, HIE) & 16 & 1 \\
\hline Turkey (EUR, UMIE) & $6,8,11,13,16$ & 5 & Egypt (EMR, LMIE)* & 6 & 1 \\
\hline \multirow{8}{*}{$\begin{array}{l}\text { UAE (United Arab Emirates) } \\
\text { (EMR, HIE) }\end{array}$} & $6,8,13,16$ & 4 & Ireland (EUR, HIE) & 11 & 1 \\
\hline & & & Nigeria (SEAR, LMIE) & 11 & 1 \\
\hline & & & Norway (EUR, HIE) & & 0 \\
\hline & & & Uganda (SEAR, LIE) & 13,16 & 2 \\
\hline & & & Ukraine (EUR, LMIE) & 8 & 1 \\
\hline & & & Uncategorised & & \\
\hline & & & Lebanon (EMR, UMIE)* & 8,11 & 2 \\
\hline & & & Mauritius (SEAR, UMIE) & 16 & 1 \\
\hline
\end{tabular}

Articles include the following: Article 6: price and tax measured to reduce demand for tobacco; Article 8: protection from exposure to tobacco smoke; Article 9: regulation of the contents of tobacco products; Article 10: regulation of tobacco product disclosure; Article 11: packaging and labelling of tobacco products; Article 12: education, communication, training and public awareness; Article

13: tobacco advertising, promotion and sponsorship; Article 14: demand reduction measures concerning tobacco dependence and cessation; Article 15: illicit trade in tobacco products; Article 16:

sales to and by minors. We combined Articles 12 and 14 in this analysis.

${ }^{*}$ Countries with state-owned tobacco companies.

AFR, African Region; AMR, Region of the Americas; EMR, East Mediterranean Region; EUR, European Region; FCTC, Framework Convention on Tobacco Control; HIE, high-income economy; LIE، low-income economy; LMIE, low middle-income economy; SEAR, South-East Asia Region; UMIE, upper middle-income economy; WB, World Bank; WPR, Western Pacific Region; WT, waterpipe tobacco. 
Association of country categorisation with extent of inclusion of WT regulation specific to FCTC articles

Country waterpipe policy categorisation seemed linked to the number of FCTC articles included in their policy: $75 \%$ of the countries (3 of 4 ) that included WT in relation to seven of the FCTC articles and only $22 \%$ of the countries (4 of 18) that included WT in relation to only one or two of the articles were ranked in category 1 . Contrarily, $50 \%$ of the countries (9 of 18) that included WT in relation to one to two FCTC articles were ranked in category 4 (A or B), whereas only one of the countries in that category included WT in relation to more than three FCTC articles (table 3).

Notably, in relation to the potential for SOTC to influence the endgame, five of eight $(62.5 \%)$ countries that have monopolies were in category 1 , and $75 \%$ of the countries that included WT content related to seven of the FCTC articles are SOTC (table 3).

\section{Equity analysis of policies and prevalence data}

For each equity axis of the PROGRESS framework, we provide examples of how it is referenced in country policies. We then include the number of countries that have prevalence data related to each equity axis and describe the findings. Table 4 lists which PROGRESS equity considerations are referenced in the policies of each country and includes prevalence data disaggregated by equity axis and country where available (we combined some of the data as noted in table 4).

\section{P: place of residence}

Only a few countries $(n=12,25.5 \%)$ include reference to place of residence within the text of their policies. For example, in the United Arab Emirates, the law prohibits selling in proximity to residential buildings and districts. Prevalence data were extracted for five countries based on urban/rural indicators. Differences were not consistent, such that in India and the Philippines the reported rural prevalence of WTS was higher than in urban areas, whereas in Ukraine, Russia and Vietnam the reported urban WTS prevalence was higher than that in rural areas.

\section{R: race/ethnicity/culture/language}

In this equity axis, language is the most noted factor in country WT policies, followed by race/ethnicity. Overall, thirteen countries $(27.7 \%)$ include reference to this equity axis. Of these, twelve countries require educational materials or warnings to be in more than one language (including sign language). For example, in Nigeria, Rwanda and Uganda, notices are requested in English and at least one predominant local language. Race and ethnicity are referenced in the WT policy only in Costa Rica insofar as the law prohibits discrimination towards those seeking treatment for tobacco-related addictions. No WT prevalence data were found to be reported by race/ethnicity/culture/ language in any of the countries that have WT policies.

\section{0: occupation}

Workplaces were mentioned in $36(76.6 \%)$ country WT policies as a location prohibiting WTS or requiring reduction of exposure to WT smoke. In addition, Afghanistan, Iraq, Kenya, Nigeria, Turkey, Vietnam and Yemen noted the need to respect tobacco farmers and other relevant professions and called for the creation and facilitation of opportunities to pursue different employment. Two countries-India and Vietnam-reported WTS prevalence by occupation. For example, in India, individuals who were retired or unemployed or had other occupations reported a $0.77 \%$ WTS prevalence and $0.75 \%$ among those employed at any level. ${ }^{41}$

\section{G: gender/sex}

Twelve countries $(25.5 \%)$ mentioned gender in WT policies. In nine country policies, gender or sex is includedmainly through reference to pregnant or puerperal women, or women of reproductive age. In addition, Afghanistan addresses gender by calling for a reduction in the production and importation of waterpipe sold to women, and Niger also calls for reinforcing measures to combat smoking among women. Terms used to identify gender or sex in the reports of prevalence data include 'men', 'women', 'female', 'male', 'girls' and 'boys'. This equity indicator was the most reported on in the prevalence data, and all countries reporting prevalence data included a measure of gender or sex. Males, men and boys were more likely to have higher prevalence of WTS than females, women or girls. We noted that in $\mathrm{Iraq}^{42}$ and Vietnam ${ }^{43}$ the prevalence of WTS among men was collected, but not among women, which we consider an inequity in measurement.

\section{R: religion}

Religion was noted in the WT policies of 15 countries (32\%). For example, in Poland, government institutions are requested to work with organised religion associations to protect public health against the effects of tobacco use. In Brazil, the prohibition of WTS in public places excludes places of religious worship where rituals include the use of smoking (tobacco or non-tobacco) products. In Afghanistan, the law mentions the support of Islamic Shari'ah Law in banning waterpipe. None of the databases used collected information on WTS prevalence by any measure of religion.

\section{E: education}

A majority of the countries with WT policies $(n=37,78.7 \%)$ reference education by calling for school curricula to include education on harm from tobacco and considering educational institutions as spaces to reduce exposure to tobacco harm or ban sales of tobacco products. 'Students' were also often mentioned in the policy in terms of addressing harms and reducing exposure and selling of tobacco to students. Five countries reported prevalence data by categories of education. In India, Vietnam and the Philippines, those with education at primary level or lower had higher prevalence of WTS than those with secondary or above education.

\section{S: socioeconomic status}

Four country $(0.09 \%)$ policies reference this equity measure. In Costa Rica, the law prohibits discrimination on the basis of socioeconomic status for those seeking treatment for tobaccorelated addictions. Vietnam and Turkey note the need to support tobacco farmers/producers in disadvantaged areas to ensure an alternative livelihood. Only the Philippines reported WTS prevalence by socioeconomic status, with findings noting that lower wealth quintiles in rural areas had a higher prevalence of WTS than higher wealth quintiles in urban areas.

\section{S: social capital}

Social capital was not specifically included in any of the WT country policies, but many countries' $(n=41,87.2 \%)$ policies list locations where WTS is prohibited. Since many of these places are public spaces, they could be considered linked to social capital. Several laws also required the design of educational programmes 
Table 4 Country WT policy category and prevalence of WTS by PROGRESS indicator

\begin{tabular}{|c|c|c|c|c|c|c|c|c|c|}
\hline Country & $\begin{array}{l}\text { Category of } \\
\text { WTS policy }\end{array}$ & $\begin{array}{l}\text { Number } \\
\text { of articles } \\
\text { that } \\
\text { include } \\
\text { WTS }\end{array}$ & $\begin{array}{l}\text { PROGRESS equity } \\
\text { axes addressed } \\
\text { in the country } \\
\text { policy }\end{array}$ & $\begin{array}{l}\text { Equity axes data } \\
\text { abstracted from } \\
\text { data sources }\end{array}$ & Country & $\begin{array}{l}\text { Category of } \\
\text { WTS policy }\end{array}$ & $\begin{array}{l}\text { Number of } \\
\text { articles that } \\
\text { include WTS }\end{array}$ & $\begin{array}{l}\text { PROGRESS } \\
\text { equity axes } \\
\text { addressed in the } \\
\text { country policy }\end{array}$ & $\begin{array}{l}\text { Equity axes data } \\
\text { abstracted from } \\
\text { data sources }\end{array}$ \\
\hline Afghanistan & 2 & 8 & $\begin{array}{l}\text { Social capital, } \\
\text { occupation, } \\
\text { education, religion, } \\
\text { gender. }\end{array}$ & No data available. & Pakistan & 1 & 2 & $\begin{array}{l}\text { Social capital, } \\
\text { education, } \\
\text { occupation. }\end{array}$ & No data available. \\
\hline Azerbaijan ${ }^{46}$ & 1 & 4 & $\begin{array}{l}\text { Social capital, } \\
\text { place of residence } \\
\text { education, } \\
\text { occupation. }\end{array}$ & $\begin{array}{l}\text { Gender: } \\
\text { Male: } 4.80 \% \\
\text { Female: } 24: 60 \%\end{array}$ & $\begin{array}{l}\text { Kingdom of Saudi } \\
\text { Arabia }\end{array}$ & 1 & 6 & $\begin{array}{l}\text { Religion, } \\
\text { education, } \\
\text { occupation, social } \\
\text { capital. }\end{array}$ & $\begin{array}{l}\text { Gender: } \\
\text { Male: } 9.70 \% \\
\text { Female: } 2.30 \%{ }^{47} \\
\text { Boys: } 3.30 \% \\
\text { Girls: } 1.60 \%{ }^{48}\end{array}$ \\
\hline Bahrain $^{49}$ & 2 & 1 & $\begin{array}{l}\text { Social capital, } \\
\text { occupation, } \\
\text { education, religion. }\end{array}$ & $\begin{array}{l}\text { Gender: } \\
\text { Boys: } 12.70 \% \\
\text { Girls: } 5.80 \%\end{array}$ & Panama $^{50}$ & 1 & 5 & $\begin{array}{l}\text { Education, } \\
\text { social capital, } \\
\text { occupation, SES. }\end{array}$ & $\begin{array}{l}\text { Gender: } \\
\text { Boys: } 2.50 \% \\
\text { Girls: } 2.30 \%\end{array}$ \\
\hline Brazil & $4 \mathrm{~A}$ & 3 & $\begin{array}{l}\text { Social capital, } \\
\text { religion, } \\
\text { occupation, } \\
\text { education. }\end{array}$ & No data available. & Philippines $^{51}$ & 1 & 5 & $\begin{array}{l}\text { Education, social } \\
\text { capital. }\end{array}$ & $\begin{array}{l}\text { Education: } \\
\text { Primary school or } \\
\text { less: } 0.45 \% \\
\text { Secondary or above: } \\
0.40 \% \\
\text { Place of residence: } \\
\text { Urban: } 0.20 \% \\
\text { Rural: } 0.60 \% \\
\text { Wealth index } \\
\text { quintile: } \\
\text { Highest index } \\
\text { quintile (urban): } \\
0.30 \% \\
\text { Lowest index } \\
\text { quintile (rural): } \\
0.70 \% \\
\text { Gender: } \\
\text { Male: } 0.70 \% \\
\text { Female: } 0.20 \% \\
\text { Boys: } 4.30 \% \\
\text { Girls: } 2.50 \% 52\end{array}$ \\
\hline Bulgaria $^{53}$ & 3 & 1 & $\begin{array}{l}\text { Social capital, } \\
\text { education, } \\
\text { occupation. }\end{array}$ & $\begin{array}{l}\text { Gender: } \\
\text { Boys: } 17.20 \% \\
\text { Girls: } 16.50 \%\end{array}$ & Poland & 3 & 1 & $\begin{array}{l}\text { Social capital, } \\
\text { occupation, } \\
\text { education, } \\
\text { religion. }\end{array}$ & No data available. \\
\hline Chad & 1 & 1 & $\begin{array}{l}\text { Social capital, } \\
\text { occupation, } \\
\text { education, gender. }\end{array}$ & No data available. & Portugal & 3 & 6 & $\begin{array}{l}\text { Social capital, } \\
\text { occupation, } \\
\text { education, place } \\
\text { of residence, } \\
\text { gender, race/ } \\
\text { ethnicity. }\end{array}$ & No data available. \\
\hline Costa Rica $^{54}$ & 1 & 5 & $\begin{array}{l}\text { Gender, social } \\
\text { capital, occupation, } \\
\text { education, religion, } \\
\text { race, SES. }\end{array}$ & $\begin{array}{l}\text { Gender: } \\
\text { Boys: } 6.00 \% \\
\text { Girls: } 5.10 \%\end{array}$ & Russia $^{55}$ & 2 & 6 & $\begin{array}{l}\text { Social capital, } \\
\text { education, } \\
\text { occupation, place } \\
\text { of residence. }\end{array}$ & $\begin{array}{l}\text { Place of residence: } \\
\text { Rural: } 1.40 \% \\
\text { Urban: } 3.20 \% \\
\text { Education: } \\
\text { Primary school or } \\
\text { less: } 0.90 \% \\
\text { Secondary or above: } \\
3.00 \% \\
\text { Gender: } \\
\text { Male: } 4.10 \% \\
\text { Female: } 1.70 \% \\
\text { Boys: } 7.90 \% \\
\text { Girls: } 7.20 \%{ }^{56}\end{array}$ \\
\hline Czech Republic $^{57}$ & 3 & 4 & & $\begin{array}{l}\text { Gender: } \\
\text { Boys: } 10.40 \% \\
\text { Girls: } 7.80 \%\end{array}$ & Rwanda & $4 \mathrm{~A}$ & 3 & $\begin{array}{l}\text { Race, religion, } \\
\text { education, } \\
\text { occupation, social } \\
\text { capital. }\end{array}$ & No data available. \\
\hline Ecuador & 1 & 5 & $\begin{array}{l}\text { Social capital, } \\
\text { occupation, } \\
\text { education, place of } \\
\text { residence. }\end{array}$ & No data available. & Scotland & 3 & 3 & Social capital. & No data available. \\
\hline England & 3 & 4 & & No data available. & Serbia $^{58}$ & 1 & 2 & $\begin{array}{l}\text { Social capital, } \\
\text { occupation, } \\
\text { education. }\end{array}$ & $\begin{array}{l}\text { Gender: } \\
\text { Boys: } 9.20 \% \\
\text { Girls: } 8.70 \%\end{array}$ \\
\hline
\end{tabular}




\begin{tabular}{|c|c|c|c|c|c|c|c|c|c|}
\hline Country & $\begin{array}{l}\text { Category of } \\
\text { WTS policy }\end{array}$ & $\begin{array}{l}\text { Number } \\
\text { of articles } \\
\text { that } \\
\text { include } \\
\text { WTS }\end{array}$ & $\begin{array}{l}\text { PROGRESS equity } \\
\text { axes addressed } \\
\text { in the country } \\
\text { policy }\end{array}$ & $\begin{array}{l}\text { Equity axes data } \\
\text { abstracted from } \\
\text { data sources }\end{array}$ & Country & $\begin{array}{l}\text { Category of } \\
\text { WTS policy }\end{array}$ & $\begin{array}{l}\text { Number of } \\
\text { articles that } \\
\text { include WTS }\end{array}$ & $\begin{array}{l}\text { PROGRESS } \\
\text { equity axes } \\
\text { addressed in the } \\
\text { country policy }\end{array}$ & $\begin{array}{l}\text { Equity axes data } \\
\text { abstracted from } \\
\text { data sources }\end{array}$ \\
\hline Egypt & $4 \mathrm{~B}$ & 1 & Social capital. & $\begin{array}{l}\text { Gender: } \\
\text { Male: } 8.70 \% \\
\text { Female: } 0.10 \%{ }^{59} \\
\text { Boys: } 8.50 \% \\
\text { Girls: } 2.40 \%{ }^{60}\end{array}$ & Singapore & 2 & 2 & & No data available. \\
\hline Estonia $^{61}$ & $4 \mathrm{~B}$ & 1 & $\begin{array}{l}\text { Social capital, } \\
\text { occupation, } \\
\text { education, place of } \\
\text { residence. }\end{array}$ & $\begin{array}{l}\text { Gender: } \\
\text { Boys: } 6.47 \% \\
\text { Girls: } 5.03 \%\end{array}$ & Slovakia $^{62}$ & 3 & 2 & $\begin{array}{l}\text { Social capital, } \\
\text { race/language. }\end{array}$ & $\begin{array}{l}\text { Gender: } \\
\text { Boys: } 8.40 \% \\
\text { Girls: } 6.50 \%\end{array}$ \\
\hline France $^{63}$ & 1 & 4 & $\begin{array}{l}\text { Social capital, } \\
\text { occupation, } \\
\text { education, place of } \\
\text { residence. }\end{array}$ & $\begin{array}{l}\text { Gender: } \\
\text { Boys: } 4.60 \% \\
\text { Girls: } 4.00 \%\end{array}$ & Slovenia & 3 & 6 & $\begin{array}{l}\text { Social capital, } \\
\text { education, } \\
\text { occupation, race/ } \\
\text { language. }\end{array}$ & No data available. \\
\hline India $^{41}$ & 1 & 1 & $\begin{array}{l}\text { Social capital, } \\
\text { occupation, } \\
\text { education, place of } \\
\text { residence, gender, } \\
\text { race. }\end{array}$ & $\begin{array}{l}\text { Place of residence: } \\
\text { Rural: } 0.90 \% \\
\text { Urban: } 0.30 \% \\
\text { Occupation: } \\
\text { Unemployed, } \\
\text { elementary or } \\
\text { other: } 0.77 \% \\
\text { Employed at any } \\
\text { level: } 0.75 \% \\
\text { Gender: } \\
\text { Men: } 1.10 \% \\
\text { Women: } 0.30 \% \\
\text { Education: } \\
\text { Primary school or } \\
\text { less: } 0.83 \% \\
\text { Secondary or } \\
\text { above: } 0.40 \%\end{array}$ & Sweden & 3 & 1 & & No data available. \\
\hline Iraq & 1 & 5 & $\begin{array}{l}\text { Race/ethnicity, } \\
\text { social capital, } \\
\text { occupation, } \\
\text { education, religion. }\end{array}$ & $\begin{array}{l}\text { Gender: } \\
\text { Male: } 10.30 \% \\
\text { Female: N/A } \\
\text { Boys: } 8.90 \% \\
\text { Girls: } 6.00 \%{ }^{42}\end{array}$ & Syria $^{65}$ & $4 \mathrm{~A}$ & 5 & $\begin{array}{l}\text { Social capital, } \\
\text { religion, } \\
\text { education, } \\
\text { occupation, } \\
\text { gender, race/ } \\
\text { language. }\end{array}$ & $\begin{array}{l}\text { Gender: } \\
\text { Boys: } 32.00 \% \\
\text { Girls: } 18.00 \%\end{array}$ \\
\hline Ireland & $4 C$ & 1 & & No data available. & Thailand $^{66}$ & $4 \mathrm{~A}$ & 1 & $\begin{array}{l}\text { Social capital, } \\
\text { occupation, } \\
\text { education, gender, } \\
\text { religion. }\end{array}$ & $\begin{array}{l}\text { Gender: } \\
\text { Boys: } 4.70 \% \\
\text { Girls: } 1.90 \%\end{array}$ \\
\hline Kenya & $4 \mathrm{~A}$ & 2 & $\begin{array}{l}\text { Social capital, race, } \\
\text { education, religion, } \\
\text { occupation. }\end{array}$ & No data available. & Turkey & 2 & 5 & $\begin{array}{l}\text { Occupation, social } \\
\text { capital, education, } \\
\text { gender, religion, } \\
\text { race/ethnicity, SES. }\end{array}$ & No data available. \\
\hline Lebanon & $\mathrm{N} / \mathrm{A}$ & 2 & $\begin{array}{l}\text { Social capital, } \\
\text { occupation, } \\
\text { education. }\end{array}$ & No data available. & $\begin{array}{l}\text { United Arab } \\
\text { Emirates }^{67}\end{array}$ & 2 & 4 & $\begin{array}{l}\text { Social capital, } \\
\text { religion, } \\
\text { education, } \\
\text { occupation, place } \\
\text { of residence, race/ } \\
\text { language. }\end{array}$ & $\begin{array}{l}\text { Gender: } \\
\text { Boys: } 18.70 \% \\
\text { Girls: } 7.60 \%\end{array}$ \\
\hline Mauritius & $\mathrm{N} / \mathrm{A}$ & 1 & $\begin{array}{l}\text { Social capital, } \\
\text { education, } \\
\text { occupation. }\end{array}$ & No data available. & Uganda $^{68}$ & $4 \mathrm{~B}$ & 2 & $\begin{array}{l}\text { Social capital, } \\
\text { religion, } \\
\text { education, } \\
\text { occupation, race. }\end{array}$ & $\begin{array}{l}\text { Gender: } \\
\text { Boys: } 10.03 \% \\
\text { Girls: } 9.27 \%\end{array}$ \\
\hline Moldova & 1 & 7 & $\begin{array}{l}\text { Social capital, } \\
\text { gender, occupation, } \\
\text { education. }\end{array}$ & No data available. & Ukraine $^{69}$ & $4 \mathrm{~B}$ & 1 & $\begin{array}{l}\text { Education, } \\
\text { social capital, } \\
\text { occupation, place } \\
\text { of residence. }\end{array}$ & $\begin{array}{l}\text { Place of residence: } \\
\text { Urban: } 0.90 \% \\
\text { Rural: } 0.30 \% \\
\text { Education: } \\
\text { Primary school or } \\
\text { less: N/A } \\
\text { Secondary or above: } \\
0.50 \% \\
\text { Gender: } \\
\text { Male } 1.30 \% \\
\text { Female: } 0.30 \%\end{array}$ \\
\hline
\end{tabular}


Table 4 Continued

\begin{tabular}{|c|c|c|c|c|c|c|c|c|c|}
\hline Country & $\begin{array}{l}\text { Category of } \\
\text { WTS policy }\end{array}$ & $\begin{array}{l}\text { Number } \\
\text { of articles } \\
\text { that } \\
\text { include } \\
\text { WTS }\end{array}$ & $\begin{array}{l}\text { PROGRESS equity } \\
\text { axes addressed } \\
\text { in the country } \\
\text { policy }\end{array}$ & $\begin{array}{l}\text { Equity axes data } \\
\text { abstracted from } \\
\text { data sources }\end{array}$ & Country & $\begin{array}{l}\text { Category of } \\
\text { WTS policy }\end{array}$ & $\begin{array}{l}\text { Number of } \\
\text { articles that } \\
\text { include WTS }\end{array}$ & $\begin{array}{l}\text { PROGRESS } \\
\text { equity axes } \\
\text { addressed in the } \\
\text { country policy }\end{array}$ & $\begin{array}{l}\text { Equity axes data } \\
\text { abstracted from } \\
\text { data sources }\end{array}$ \\
\hline Niger & $4 \mathrm{~A}$ & 1 & $\begin{array}{l}\text { Social capital, } \\
\text { occupation, } \\
\text { education, gender. }\end{array}$ & No data available. & Vietnam $^{43}$ & 1 & 7 & $\begin{array}{l}\text { Social capital, } \\
\text { occupation, place } \\
\text { of residence, } \\
\text { gender, education, } \\
\text { SES. }\end{array}$ & $\begin{array}{l}\text { Place of residence: } \\
\text { Urban: } 0.20 \% \\
\text { Rural: } 0.10 \% \\
\text { Education: } \\
\text { Primary school or } \\
\text { less: } 0.20 \% \\
\text { Secondary or above: } \\
0.10 \% \\
\text { Occupation: } \\
\text { Unemployed, } \\
\text { elementary or other: } \\
0.15 \% \\
\text { Employed at any } \\
\text { level: N/A } \\
\text { Gender: } \\
\text { Male } 0.20 \% \\
\text { Female: N/A }\end{array}$ \\
\hline Nigeria & $4 \mathrm{~B}$ & 1 & $\begin{array}{l}\text { Social capital, } \\
\text { occupation, } \\
\text { education, gender, } \\
\text { place of residence, } \\
\text { race. }\end{array}$ & No data available. & Wales & 3 & 3 & & No data available. \\
\hline Northern Ireland & 3 & 3 & Social capital. & No data available. & Yemen $^{70}$ & 1 & 7 & $\begin{array}{l}\text { Social capital, } \\
\text { education, } \\
\text { occupation, } \\
\text { religion. }\end{array}$ & $\begin{array}{l}\text { Gender: } \\
\text { Boys: } 12.40 \% \\
\text { Girls: } 5.60 \%\end{array}$ \\
\hline Norway & 3 & 0 & $\begin{array}{l}\text { Social capital, } \\
\text { place of residence, } \\
\text { occupation, } \\
\text { education. }\end{array}$ & No data available. & & & & & \\
\hline
\end{tabular}

In the table, we report data from the databases only for current smokers who are 15 years of age or older for all indicators except for those referring to boys and girls, where the indicators report for current smokers younger than 15 years of age. Because of this manipulation, data are only reported for 23 countries, as opposed to 25 (Bulgaria only reported data for youth under the cutoff point of 15 years of age, such that place of residence is extracted for only five countries instead of 6; and Ecuador and Sweden reported data among adolescents including populations aged 15 and above, so that prevalence among boys and girls is extracted for 19 countries instead of 21). We dichotomised response options of the various equity indicators. For education, we used 'primary school or less' and 'secondary school or above.' For SES, we reported highest income quintile in urban populations and lowest income quintile among rural populations. For occupation, we reported those 'employed at any level' and those 'unemployed, [employed at] 'elementary' [level] or [holding] other (types of employment)'. For countries that reported on one or more types of shisha including 'traditional waterpipe' or 'waterpipe without tobacco', we chose the tobacco product most closely related to a shisha/hookah/waterpipe to ensure comparability across data. In the cases where there was more than one indicator reported for any given aggregated category, we decided to report a mean. Lastly, for countries where waterpipe tobacco smoking prevalence was reported over two or more data sets, we used the most recent report, complementing with data from other reports to fit the PROGRESS indicators where appropriate and where data were missing. As a result, from the reports that met the eligibility criteria in the prevalence data search, the table presents data from 18 out of 20 FCTC implementation reports, 6 out of the 6 GATS reports, 1 out of the 3 GYTS reports, 3 out of the 3 WHO STEPS reports and 0 out of the 1 DHS report.

Of the 47 countries with WT in their policies, only 25 reported at least one measure of WTS prevalence in any of the sources reviewed. These included the FCTC implementation reports (which included 20 countries), Global Adult Tobacco Survey (GATS) (6 countries), Gloabl Youth Tobacco Survey (GYTS) (3 countries), WHO STEPS (STEPwise approach to surveillance) (3 countries) and Demographic and Health Surveys (DHS) (one country). The data reviewed dated from 2015 until March 2020.

FCTC, Framework Convention on Tobacco Control; PROGRESS, place of residence, race, occupation,gender, religion, education, socioeconomic status, social capital; SES, socioeconomic status; WT, waterpipe tobacco; WTS, waterpipe tobacco smoking.

and other awareness-raising exercises, as well as community support for those seeking help for quitting. Given that these can be interpreted as advocacy and community-oriented activities, we also considered them linked to social capital. Social capital was not reported across any prevalence data sets.

The comparison between equity indicators included in country policies with those included in prevalence data suggested a disconnect and lack of synergy between the goals of surveillance and those of policy development (table 4). Only 8 of 25 countries have at least one PROGRESS indicator consistent across policy and prevalence data.

\section{DISCUSSION}

This paper has updated Jawad et al's ${ }^{38}$ scan of country WT control policies worldwide and enhanced the analysis by adding an equity lens. Jawad et al's ${ }^{38}$ paper identified 11 countries with WTS-related policies. We identified further 40 new WTS policies and excluded four countries from Jawad et $a l^{38}$ based on our eligibility criteria. Hence we had a total of 47 countries with WTS-related policies. Our findings also showed that since 2015 China, Iran, Syria and Uganda have updated their WTS policies. The Jawad $e$ t $a l^{38}$ study reviewed policies in relation to Articles 8, 11 and 13 of the FCTC and we expanded the review to consider Articles 6 and 8-16. We also expanded our review to include equity in WTS-related policies as well as in WTS prevalence data.

Broadly, we continue to find very superficial policy attention to WT, despite its wide prevalence globally; only $45 \%$ of the countries are in categories 1 and 2, and only $8 \%$ include content related to WTS in relation to seven FCTC articles.

Interestingly, countries with SOTC seem to have potentially stronger/more specific WT policies; $75 \%$ of those that included content related to seven FCTC articles are SOTC, and 62\% of these countries are classified as category 1 or 2 , as opposed to $38 \%$ of countries without SOTC. Hogg et al ${ }^{21}$ note that there is potential for 'partial interest alignment' between SOTC and endgame goals in relation to FCTC guidance for countries that encourage the government 'to impose a requirement (on SOTC) to consider social and environmental consequences and to take certain steps to address those consequences' (p370). 
Smith et $a l^{22}$ suggest that the merging of state-owned alcohol companies with SOTC could increase the coherence of policies across substances and advance endgame goals.

With respect to our equity analysis, there was no clear calling out of equity as a goal of WTS policies. To date, there has been no assessment of WTS policies in relation to their impact on equity, despite literature on the inequities resulting from broader tobacco control policies. ${ }^{19-22} 2425$ Cognisant of the dearth of data, we used a straightforward framework to limit complexity of analysis. The PROGRESS framework allows for the extension of analysis of prevalence data towards 'social, behavioral, economic and environmental determinants'. ${ }^{26}$ Yet, even with the simple PROGRESS analysis, we found very little data that allow a determination of the impact of WTS policies on equity. Further, we found a disconnect between the equity indicators included in a policy and the prevalence data collected, and neither seemed to inform the other. Surveillance is critical for policy evaluation, and at a minimum countries should synergise goals of policy and surveillance. However, more importantly, advancing equity considerations in WTS policy is critical to decreasing disparities and promoting justice. Dialogue is needed within the tobacco control community around the most appropriate equity framework for policy analysis and data collection.

We grouped countries into four categories. Although category 1 includes countries that clearly defined waterpipe as part of their tobacco product definition and thus, in principle, regulate it in other policy parts, in line with the FCTC articles, we cannot make conclusions as to the strength of those policies without looking more carefully at the nature of the regulation and the extent to which it addressed the uniqueness of WTS. ${ }^{1112}$ For example, although $73 \%$ of the countries in category 1 address Article 11, it is unclear if their guidance is tailored to WT. Category 2 may therefore be the preferred policy strategy. Convening an expert group to develop consensus around indicators of relevance, strength

What this paper adds

What is already known on this subject

- The increase in waterpipe tobacco smoking (WTS) globally has been linked to a variety of factors, one of which is the lack of waterpipe-specific policies and regulations.

- A growing body of literature has documented the need for regulatory practices to control WTS.

- Previous global analysis of country tobacco control policies in 2015 indicated that very few country policies addressed WTS.

What important gaps in knowledge exist on this topic

- Since 2015, there have been no updates on the progress of countries in addressing WTS in their legislation.

- Despite existing evidence of the potential of evidence-based tobacco control policies to increase health inequities, no one has looked at waterpipe tobacco control policies using a health equity lens.

What this paper adds

- Globally, despite the growing acknowledgement of the importance of WTS policies, the number of countries that have regulations in place to address WTS comprehensively has not increased.

- Equity considerations do not seem to be influencing existing waterpipe tobacco control policies. and specificity in relation to WTS-specific policies would advance the field.

Several constraints to our methodology of analysis influence our results. For the policy analysis, we used the Tobacco-Free Kids website as our primary source. The English translations may not have been an accurate rendition of the original language. Also, we only included countries that explicitly used the word waterpipe or its related word/synonyms in their policies, which may have limited the validity of categorisation. Our analysis focused on the content of policies, and not on the form of their implementation. ${ }^{44}$ For the prevalence data, our review of databases was not comprehensive, rather focused on potential comparability across countries. Data were very scarce, challenging comparability and preventing the assessment of policy impact.

Several recommendations arise from the comprehensive review of policies and prevalence data carried out for this paper. For the policy analysis, the complexity of developing WTS-specific policies and the implication of that complexity for other Alternative tobacco products (ATPs) highlight the challenge of developing and implementing tailored tobacco control policies. This is further confounded by the variety of stakeholders relevant to each ATP. Tobacco industry interference needs to continuously be assessed throughout this process. Moreover, countries considering the endgame strategy and working towards the $5 \%$ prevalence rate need to include WTS as one of the tobacco products to address more comprehensively. Regarding equity, we recommend that policies and surveillance centre equity as a goal in their policy documents. Policy and surveillance should be aligned on equity considerations. Further, a discussion is needed among global tobacco control advocates about the most relevant equity frameworks.

\section{CONCLUSION}

The review in this manuscript provides a starting point for policy review and monitoring of FCTC implementation specific to WTS (and other ATPs) ${ }^{45}$ and for a deeper consideration of the equity implications of WTS policies. The results provide data that researchers and advocates in those countries can use in their work to enhance policies, reduce WTS and promote equity. Future FCTC COP are advised to build on this current review and use information to push for stronger WTSspecific and equitable policies spanning the FCTC articles and to pressure countries that have particularly high prevalence rates to better address WTS.

\section{Twitter Rima Nakkash @rimanakkash}

Contributors RN and RA conceptualised and supervised and reviewed the paper. HA and LEK worked on the policy analysis components. SKR and MT worked on the equity analysis component. All authors participated in writing, discussed the results and contributed to the final manuscript. RN is the guarantor.

Funding The authors have not declared a specific grant for this research from any funding agency in the public, commercial or not-for-profit sectors.

Competing interests None declared.

Patient consent for publication Not required.

Ethics approval This study does not involve human participants.

Provenance and peer review Commissioned; externally peer reviewed.

Data availability statement No data are available.

Supplemental material This content has been supplied by the author(s). It has not been vetted by BMJ Publishing Group Limited (BMJ) and may not have been peer-reviewed. Any opinions or recommendations discussed are solely those of the author(s) and are not endorsed by BMJ. BMJ disclaims all liability and responsibility arising from any reliance placed on the content. Where the content includes any translated material, BMJ does not warrant the accuracy and reliability 
of the translations (including but not limited to local regulations, clinical guidelines, terminology, drug names and drug dosages), and is not responsible for any error and/or omissions arising from translation and adaptation or otherwise.

\section{ORCID iDs}

Hala Alaouie http://orcid.org/0000-0002-8286-9476

Rima A Afifi http://orcid.org/0000-0003-3154-3617

Rima Nakkash http://orcid.org/0000-0001-8800-5591

\section{REFERENCES}

1 Jawad M, Charide R, Waziry R, et al. The prevalence and trends of waterpipe tobacco smoking: a systematic review. PLoS One 2018;13:e0192191.

2 Pratiti R, Mukherjee D. Epidemiology and adverse consequences of hookah/waterpipe use: a systematic review. Cardiovasc Hematol Agents Med Chem 2019;17:82-93.

3 Waziry R, Jawad M, Ballout RA, et al. The effects of waterpipe tobacco smoking on health outcomes: an updated systematic review and meta-analysis. Int J Epidemiol 2017:46:32-43.

4 El-Zaatari ZM, Chami HA, Zaatari GS. Health effects associated with waterpipe smoking. Tob Control 2015;24 Suppl 1:i31-43.

5 Organization WH. Advisory note: waterpipe tobacco smoking: health effects, research needs and recommended actions by regulators.. In: Advisory note: waterpipe tobacco smoking: health effects, research needs and recommended actions by regulators. 2, 2015.

6 Ahmed B, Jacob III P, Allen F. Attitudes and practices of hookah smokers in the San Francisco Bay area. J Psychoactive Drugs 2011;43:146-52.

7 Martin R, Safaee SD, Somsamouth K, et al. Mixed methods pilot study of sharing behaviors among waterpipe smokers of rural Lao PDR: implications for infectious disease transmission. Int J Environ Res Public Health 2013;10:2120-32.

8 Akl EA, Ward KD, Bteddini D, et al. The allure of the waterpipe: a narrative review of factors affecting the epidemic rise in waterpipe smoking among young persons globally. Tob Control 2015;24 Suppl 1:113-21.

9 Lopez AA, Eissenberg T, Jaafar M, et al. Now is the time to advocate for interventions designed specifically to prevent and control waterpipe tobacco smoking. Addict Behav 2017:66:41-7.

10 Sutfin EL, Soule EK, McKelvey K, et al. Implications and challenges for implementation of the FDA's final deeming rule for waterpipe tobacco. Tob Control 2018;27:347-51.

11 Farran D, Khawam G, Nakkash R, et al. Association of health warning labels and motivation to quit waterpipe tobacco smoking among university students in the eastern Mediterranean region. Tob Prev Cessat 2021;7:1-10.

12 Asfar T, Schmidt M, Ebrahimi Kalan M, et al. Delphi study among international expert panel to develop waterpipe-specific health warning labels. Tob Control 2020:29:159-67.

13 Salloum RG, Abu-Rmeileh N, Hamadeh R, et al. Policy-Relevant context of waterpipe tobacco smoking among university students in six countries across the eastern Mediterranean region: a qualitative study. Asian Pac J Cancer Prev 2017;18:2533.

14 Organization WH. Control and prevention of waterpipe tobacco products report. Geneva: World Health Organization, 2016.

15 Maziak W, Sharma E. Building the evidence base for waterpipe regulation and policy. Tob Control 2020;29:s59-61.

16 FCTC. Impact assessment of the who FCTC: report by the expert group. Conference of the Parties to the WHO Framework Convention on Tobacco Contro, Delhi, India, 2016.

17 Salloum RG, Asfar T, Maziak W. Toward a regulatory framework for the waterpipe. Am J Public Health 2016;106:1773-7.

18 An Overview of Global Regulatory Practices in Controlling Waterpipe Tobacco Use. WHO FCTC Secretariat's Knowledge Hub on Waterpipe Tobacco Smoking 2018.

19 Malone RE. The race to a tobacco endgame. Tob Control 2016;25:607-8.

20 Skinner A, Walker P, Atkinson J-A, et al. Policy options for endgame planning in tobacco control: a simulation modelling study. Tob Control 2021:30:77-83.

21 Hogg SL, Hill SE, Collin J. State-ownership of tobacco industry: a 'fundamental conflict of interest' or a 'tremendous opportunity' for tobacco control? Tob Control 2016;25:367-72.

22 Smith EA, McDaniel PA, Hiilamo H, et al. Policy coherence, integration, and proportionality in tobacco control: should tobacco sales be limited to government outlets? I Public Health Policy 2017:38:345-58.

23 Bhatnagar A, Whitsel LP, Blaha MJ, et al. New and emerging tobacco products and the nicotine endgame: the role of robust regulation and comprehensive tobacco control and prevention: a presidential Advisory from the American heart association. Circulation 2019;139:e937-58.

24 van der Deen FS, Wilson N, Cleghorn CL, et al. Impact of five tobacco endgame strategies on future smoking prevalence, population health and health system costs: two modelling studies to inform the tobacco endgame. Tob Control 2018;27:278-86.

25 Bhatnagar A, Maziak W, Eissenberg T, et al. Water pipe (hookah) smoking and cardiovascular disease risk: a scientific statement from the American heart association. Circulation 2019;139:e917-36.
26 Douglas MD, Josiah Willock R, Respress E, et al. Applying a health equity lens to evaluate and inform policy. Ethn Dis 2019;29:329-42.

27 Brown T, Platt S, Amos A. Equity impact of interventions and policies to reduce smoking in youth: systematic review. Tob Control 2014;23:e98-105.

28 Smith CE, Hill SE, Amos A. Impact of population tobacco control interventions on socioeconomic inequalities in smoking: a systematic review and appraisal of future research directions. Tob Control 2021;30:e87-95.

29 Brown T, Platt S, Amos A. Equity impact of population-level interventions and policies to reduce smoking in adults: a systematic review. Drug Alcohol Depend 2014;138:7-16.

30 Collin J. Global health, equity and the who framework convention on tobacco control. Glob Health Promot 2010;17:73-5.

31 Rezk-Hanna M, Holloway IW, Toyama J, et al. Transitions in hookah (waterpipe) smoking by U.S. sexual minority adults between 2013 and 2015: the population assessment of tobacco and health study wave 1 and wave 2. BMC Public Health 2021;21:1-11

32 Nasser AMA, Geng Y, Al-Wesabi SA. The prevalence of smoking (cigarette and waterpipe) among university students in some Arab countries: a systematic review. Asian Pac J Cancer Prev 2020;21:583-91.

33 PROGRESS-Plus. Cochrane methods equity: cochrane, 2021.

34 Evans T, Brown H. Road traffic crashes: operationalizing equity in the context of health sector reform. Inj Control Saf Promot 2003;10:11-12.

35 Welch V, Petticrew M, Tugwell P, et al. PRISMA-Equity 2012 extension: reporting guidelines for systematic reviews with a focus on health equity. PLoS Med 2012;9:e1001333.

36 Tobacco control laws. Available: https://www.tobaccocontrollaws.org [Accessed 01 Oct 2021]

37 Primack BA, Mah J, Shensa A, et al. Associations between race, ethnicity, religion, and waterpipe tobacco smoking. J Ethn Subst Abuse 2014;13:58-71.

38 Jawad M, El Kadi L, Mugharbil S, et al. Waterpipe tobacco smoking legislation and policy enactment: a global analysis. Tob Control 2015;24 Suppl 1:60-5.

39 Maziak W, Nakkash R, Bahelah R, et al. Tobacco in the Arab world: old and new epidemics amidst policy paralysis. Health Policy Plan 2014;29:784-94.

40 Karppinen K, Moe H. What we talk about when we talk about document analysis. In: Trends in communication policy research: new theories, methods and subjects, 2012: 177-93

41 Tata Institute of Social Sciences (TISS) Mumbai and Ministry of Health and Family Welfare Government of India. Global adult tobacco survey GATS 2 India, 2016-17.

42 Iraq. CORE questionnaire of the reporting instrument of WHO FCTC, 2020.

43 Ministry of Health of Viet Nam Hanoi Medical University general Statistics Office, WHO. Global adult tobacco survey (GATS) Viet Nam 20152016.

44 Anderson CL, Mons U, Winkler V. Global progress in tobacco control: the question of policy compliance. Glob Health Action 2020;13:1844977.

45 Saitta D, Ferro GA, Polosa R. Therapeutic advances in chronic disease, 2014.

46 Azerbaijan. NCD Microdata Repository steps, 2017.

47 GATS KSA. 2019 global adult tobacco survey, 2019

48 Saudi Arabia. CORE questionnaire of the reporting instrument of WHO FCTC, 2020.

49 Bahrain. CORE questionnaire of the reporting instrument of WHO FCTC, 2020.

50 Panama. CORE questionnaire of the reporting instrument of WHO FCTC, 2020.

51 Philippines. GATS Philippines global adult tobacco survey: country report 2015, 2015.

52 Philippines. CORE questionnaire of the reporting instrument of WHO FCTC, 2020.

53 Bulgaria. CORE questionnaire of the reporting instrument of WHO FCTC, 2018.

54 Costa Rica. CORE questionnaire of the reporting instrument of WHO FCTC, 2018.

55 WHO. GATS Russian Federaton global adult tobacco survey: country report 2016 2016.

56 Russian Federation. CORE questionnaire of the reporting instrument of WHO FCTC, 2020.

57 Czech Republic. CORE questionnaire of the reporting instrument of WHO FCTC, 2018.

58 Serbia. CORE questionnaire of the reporting instrument of WHO FCTC, 2020.

59 WHO. Egypt National STEPwise Survey For Noncommunicable Diseases Risk Factors Report 2017. In: CORE questionnaire of the reporting instrument of WHO FCTC, 2017.

60 Egypt. CORE questionnaire of the reporting instrument of WHO FCTC, 2020.

61 Estonia. CORE questionnaire of the reporting instrument of WHO FCTC, 2020.

62 SLOVAKIA. Country report global youth tobacco survey (GYTS), 2016.

63 France. CORE questionnaire of the reporting instrument of WHO FCTC, 2020.

64 Organization WH. Noncommunicable diseases risk factors STEPS Survey, Iraq 2015. Update, 2015.

65 Syrian Arab Republic. CORE questionnaire of the reporting instrument of WHO FCTC, 2020.

66 Thailand. CORE questionnaire of the reporting instrument of WHO FCTC, 2020.

67 United Arab Emirates. CORE questionnaire of the reporting instrument of WHO FCTC, 2020.

68 Uganda. CORE questionnaire of the reporting instrument of WHO FCTC, 2020.

69 GATS Ukraine. 2017 global adult tobacco survey, 2017.

70 Yemen. CORE questionnaire of the reporting instrument of WHO FCTC, 2018 